\title{
Immobilization of Candida antarctica Lipase B on Fumed Silica
}

\author{
Juan C. Cruz, Peter H. Pfromm*, Mary E. Rezac \\ Department of Chemical Engineering, Kansas State University, 1005 Durland Hall, Manhattan, \\ KS 66506 - 5106, USA
}

Please cite this article as: J.C. Cruz et al., Immobilization of Candida antarctica Lipase B on fumed silica, Process Biochem. 44 (2009), 62-69.

\begin{abstract}
Enzymes are usually immobilized on solid supports or solubilized when they are to be used in organic solvents with poor enzyme solubility. We have reported previously on a novel immobilization method for s. Carlsberg on fumed silica with results that reached some of the best previously reported catalytic activities in hexane for this enzyme. Here we extend our method to Candida antarctica lipase B (CALB) as an attractive target due to the many potential applications of this enzyme in solvents. Our CALB/fumed silica preparations approached the catalytic activity of commercial Novozym 435 for a model esterification in hexane at $90 \mathrm{wt} \%$ fumed silica (relative to the mass of the preparation). An intriguing observation was that the catalytic activity at first increases as more fumed silica was made available to the enzyme but then decreased precipitously when $90 \mathrm{wt} \%$ fumed silica was exceeded. This was not the case for s. Carlsberg where the catalytic activity leveled off at high relative amounts of fumed silica. We determined adsorption kinetics, performed variations of the pre-immobilization aqueous $\mathrm{pH}$, determined the stability, and applied fluorescence microscopy to the preparations. A comparison with recent concepts by Gross et al. may point towards a rationale for an optimum intermediate surface coverage for some enzymes on solid supports.

*Corresponding author: Tel: +1 785532 4312; fax: +1 7855327372
\end{abstract}


E-mail:pfromm@ksu.edu 


\section{Introduction}

Enzyme based biocatalysts are an attractive option to perform the chemical synthesis of various compounds in non-aqueous media ${ }^{1,2}$. This approach has for example proven to be promising for the production of polymers ${ }^{3,4}$, anticancer and antiviral drugs ${ }^{5}$, aromas and fragrances ${ }^{6,7}$, and surfactants ${ }^{8}$. Performing biocatalysis in organic solvents is advantageous mainly because the solubility and stability of substrates and products are increased, thereby facilitating their transformation ${ }^{1,9}$, and because undesirable reactions, including hydrolysis, racemization, polymerization, and decomposition may be reduced when compared to aqueous systems ${ }^{1,10}$.

The catalytic activity of enzymes tends to decrease sharply when they are suspended in organic solvents compared to aqueous environments ${ }^{11}$. Much effort has been focused on strategies to overcome this issue, including enzyme immobilization on porous and non-porous solid supports ${ }^{12,13}$, chemical modification of the enzymes' surfaces to improve compatibility with solvents ${ }^{14}$, protein engineering ${ }^{2}$, and enzyme co-lyophilization with different types of excipients, such as cyclodextrins ${ }^{10,15}$, crown ethers ${ }^{15-17}$, and inorganic salts ${ }^{18-20}$. Specifically, the co-lyophilization of enzymes with inorganic salts from aqueous solution, termed salt activation, has been remarkably successful. Salt activation has been reported to increase catalytic activity by three to four orders of magnitude compared to simply suspending the enzyme in the solvent ${ }^{21}$. We have recently reported a new immobilization technique based on co-lyophilization of an enzyme with commercial fumed silica (FS) ${ }^{22,23}$. The catalytic activity of subtilisin Carlsberg immobilized on fumed silica reached or even in some cases exceeded the best activities reported for salt activation while the immobilization process was somewhat simplified. Fumed silica is an amorphous material consisting of non-porous silica nanospheres fused into 
necklace-like structures, which is obtained by the hydrolysis of silicon tetra chloride in an $\mathrm{O}_{2} / \mathrm{H}_{2}$ flame ${ }^{24,25}$. Fumed silica possesses a large specific surface area and exhibits exceptional adsorptive affinity for various organic molecules in aqueous solution including proteins and polymers ${ }^{26-31}$. The adsorption of proteins onto fumed silica has been reported to be essentially irreversible ${ }^{29,32}$. Adsorption is promoted by the formation of non-covalent interactions between the available groups on the surface of the fumed silica and the carbonyl or amino groups present in the enzyme molecules ${ }^{29,32}$. In general, these interactions are electrostatic in nature and driven by the net charges of the protein and the surface, therefore, they can be repulsive or attractive ${ }^{33}$, ${ }^{34}$. The main challenge when adsorbing enzymes on solid supports is to indentify and predict the mechanisms that control these interactions, which are highly dependent on temperature, concentration, ionic strength and $\mathrm{pH}^{33}, 34$. As enzymes exhibit a tremendous chemical and physical diversity, it is expected that multiple adsorption pathways may be significant. For instance, it has been reported that a $\mathrm{pH}$ change can increase enzyme adsorption and specific catalytic activity ${ }^{35}$.

This work is aimed at extending the immobilization of enzymes on fumed silica for catalysis in hexane to Lipase B from Candida antarctica (CALB). Among lipases, CALB is one of the most recognized biocatalysts because of its high degree of selectivity in a broad range of synthetic applications of industrial importance, including kinetic resolutions, aminolysis, esterification, and transesterification ${ }^{36-38}$. We benchmark our work against the commercial preparation Novozym 435 (Novozymes A/S), which consists of CALB physically adsorbed onto a macroporous acrylic polymer resin (Lewatit VP OC 1600, Bayer).

Gross and coworkers ${ }^{39-41}$ have recently set out to further improve on the highly successful Novozym 435 by studying the protein-surface interactions. They discovered that catalytic 
activity improves with even distribution of the enzyme throughout the support and with increasing loadings/densities per area or volume of support material ${ }^{39,40}$. One concept put forth by Gross et al. is confirmed in the work with CALB presented here: optimum catalytic activity of an immobilized enzyme may be found not at low surface coverage but somewhat counter intuitively at an intermediate surface coverage.

Here we report a study of the immobilization of CALB on fumed silica by lyophilization, and the catalytic activity of the resulting preparations for a model esterification that we used previously ${ }^{6,7,42}$. Adsorption of CALB on fumed silica pre-lyophilization from aqueous solution at different $\mathrm{pH}$ levels and silica-to-enzyme ratios was investigated by fluorescence microscopy. Catalytic competency, thermal stability, and stability during storage were examined.

The somewhat surprising maximum of catalytic activity at an intermediate surface loading of the enzyme on fumed silica is rationalized in light of recent similar results by Gross et al. for the same enzyme on a different support.

\section{Materials and Methods}

\section{Materials}

Crude CALB (lyophilized; specific activity of $28 \mathrm{U} / \mathrm{mg}$ solid) was obtained from Biocatalytics, Inc. (Pasadena, CA), stored at $4^{\circ} \mathrm{C}$, and used as-received. Commercial Novozym $435{ }^{\circledR}$ was purchased from Sigma, stored at $4^{\circ} \mathrm{C}$, and used as-received. Novozym $435{ }^{\circledR}$ is reported to be CALB immobilized on macroporous acrylic particles $(0.3-0.9 \mathrm{~mm}$ diameter) with a reported catalytic activity of about 7,000 PLU/g (Propyl Laurate per gram).

Hexane (optima, as-received water content about $10 \mathrm{ppm}$ ), monobasic potassium phosphate (purity $>99 \%$ ), acetate buffer solution ( $\mathrm{pH} 4.0$, certified), sodium bicarbonate (certified ACS), 
and glacial acetic acid (optima, purity $>99.7 \%$ ) were from Fisher Scientific (Pittsburgh, PA). Fumed silica (purity of $99.8 \%$, specific surface area $258 \mathrm{~m}^{2} / \mathrm{g}$, primary particle diameter $\sim 7-50$ $\mathrm{nm}$, as reported by the manufacturer), geraniol (purity 98\%), and geranyl acetate (purity 98\%) were from Sigma-Aldrich (St. Louis, MO), and used as received. Glass vials (24 $\mathrm{ml}$ or $125 \mathrm{ml}$ for low and high wt\% fumed silica, respectively, screw-capped, flat-bottom) were used for lyophilization of the aqueous enzyme-fumed silica suspensions. Glass vials $(24 \mathrm{ml}$ or $2 \mathrm{ml}$, Teflon screw-capped, flat-bottom) were used to perform the batch activity assays.

\section{Enzyme Immobilization}

An overview of our immobilization procedure on fumed silica is given here with details available elsewhere ${ }^{22}$. Crude CALB was weighed in a glass vial followed by aqueous buffer addition, and vortexing for about 30 seconds. Fumed silica was added, and the mixture was vortexed for 2-3 minutes resulting in a visually homogeneous suspension. This suspension was sonicated for ten minutes in a water bath (room temperature) and then placed in a refrigerator at $-20^{\circ} \mathrm{C}$ for several hours until frozen. The frozen sample was then lyophilized (48h primary drying, 24h secondary drying, VirTis model 10-MR-TR; Gardiner, NY). Table 1 shows a summary of the amounts of fumed silica and buffer used to form our preparations at the various $\mathrm{wt} \%$ of fumed silica in the final $\mathrm{CALB} /$ fumed silica preparations. The fumed silica concentrations in the final preparation are calculated from the mass of crude CALB and the mass of fumed silica initially weighted in. The mass of buffer salts that may be contained in the final preparations is at most $10 \mathrm{wt} \%$ of the final preparation and was neglected for calculation of the $\mathrm{wt} \%$ fumed silica in the final preparations. 


\section{Enzyme Adsorption Kinetics}

CALB adsorption from the aqueous phase on fumed silica was followed for 9 minutes. The aqueous $\mathrm{pH}$ was pre-adjusted to $4.0,7.8$ and 9.5 using $50 \mathrm{mM}$ sodium acetate buffer, $10 \mathrm{mM}$ monobasic phosphate buffer, or $50 \mathrm{mM}$ sodium carbonate/bicarbonate buffer, respectively. The concentration in solution was measured spectrophotometrically at $595 \mathrm{~nm}$ (Bradford assay ${ }^{43}$ ). The amount of adsorbed CALB was then calculated by mass balance.

Transmission Electron Microscopy (TEM) Analysis

An FEI CM100 Transmission Electron Microscope (100 kV) equipped with an AMT digital image capturing system was used. Only enzyme preparations obtained from adsorption at $\mathrm{pH} 7.8$ were analyzed.

Imaging of Enzyme Distribution on Fumed Silica Surfaces by Confocal Scanning Laser Microscopy

CALB was labeled with Alexa Fluor ${ }^{\circledR} 488$ (Ex:494 nm, Em:519 nm) following the procedures provided by Molecular Probes. Briefly, $0.5 \mathrm{~mL}$ of CALB solution $(2 \mathrm{mg} / \mathrm{mL}$ in Phosphate Buffered Saline (PBS)) was added to a vial of reactive dye. The mixture was then stirred in the dark for 1 hour at room temperature. Unbound Alexa Fluor ${ }^{\circledR} 488$ was separated from the conjugated CALB by size exclusion chromatography (Bio-Rad Biogel P-6 size exclusion purification resin). The conjugated CALB fraction was collected and stored at $4^{\circ} \mathrm{C}$ in $\mathrm{PBS}$ buffer. Immobilization of Alexa Fluor conjugated CALB on fumed silica was then performed as described previously. To determine the distribution of CALB immobilized on fumed silica, confocal scanning laser microscopy was employed (Zeiss Pascal 5 Laser Scanning Microscope). The fluorescence emission signal was obtained through a dichroic mirror (NFT 545) and a 
$535 \pm 30 \mathrm{~nm}$ band pass filter. Images were captured through a Plan Apochromat Objective 100x, 1.4NA, and oil immersion. The distribution analysis was performed only for enzyme preparations obtained from adsorption at $\mathrm{pH} 7.8$

Analytical Methods for Assays in Hexane

Gas chromatography was used to detect geranyl acetate (product) and geraniol (reactant) in the reaction mixtures. $1 \mu 1$ of the reaction solution was injected into a Varian Model 3800 gas chromatograph (GC, FID, HP-5 crosslinked 5\% HP ME siloxane column, 30 m, 0.25 mm i.d., $0.25 \mu \mathrm{m}$ film thickness, column $120^{\circ} \mathrm{C}$, injector an detector $250^{\circ} \mathrm{C}$, split ratio $1 / 200$, Hewlett Packard). Alternatively, a capillary column DB-WAX (30 m, $0.25 \mathrm{~mm}$ i.d., linear column temperature ramp $56-200^{\circ} \mathrm{C}$ at $30^{\circ} \mathrm{C} / \mathrm{min}$; J\&W Scientific) was used.

\section{Initial Reaction Rate Measurements and Kinetic Parameters}

Initial reaction rates were measured in a solution of substrates (geraniol and acetic acid), and products formed (geranyl acetate (GerAc) and water) in hexane. The reaction rate remains essentially constant below about $20 \%$ of conversion. Thus, the initial reaction rates were determined by linear fitting of the data up to about $65 \mathrm{~min}$. The reactions were carried out catalyzed by our preparations or the commercial Novozym 435 in 24-ml vials (reaction volume 5 $\mathrm{ml}, 30 \pm 0.05^{\circ} \mathrm{C}$ ). An equivalent of 35 PLU was always employed (Table 1). Fumed silica only showed no catalytic activity.

The apparent kinetic constants (maximum velocity, $V_{m G}$, and Michaelis-Menten constant, $K_{m G}$, where $\mathrm{G}$ stands for geraniol) at $\mathrm{pH} 7.8$ were determined by carrying out the enzymatic reactions at initial geraniol concentrations ranging from $35-100 \mathrm{mM}$. The initial acid concentration was always maintained at $100 \mathrm{mM}$. Lineweaver-Burk plots were used. 


\section{Thermal Stability Measurements}

Temperature stability was investigated by measuring the initial reaction rates at 40,55 , and $70^{\circ} \mathrm{C}$ for our preparations prepared from $\mathrm{pH} 7.8$ aqueous suspensions only. Novozym 435 was also evaluated for reference.

\section{Storage Stability in Hexane}

Enzyme preparations containing $90 \mathrm{wt} \%, 95 \mathrm{wt} \%, 98.5 \mathrm{wt} \%$, and $99 \mathrm{wt} \%$ fumed silica were suspended in $5 \mathrm{~mL}$ of hexane and incubated at $30^{\circ} \mathrm{C}$ under shaker agitation $(250 \mathrm{rpm})$. After selected incubation times, the substrates were added and the product formation followed as described previously. Only enzyme preparations obtained from adsorption at $\mathrm{pH} 7.8$ were analyzed.

\section{Long-Term Storage Stability}

The long-term stabilities were determined by measuring the initial reaction rate after storage of lyophilized preparations in closed vials at $4^{\circ} \mathrm{C}$ for 6 months. Only enzyme preparations obtained from adsorption at $\mathrm{pH} 7.8$ were analyzed.

\section{Results and discussion}

Würges et al. have recently reported on a highly active immobilizate of the protease subtilisin Carlsberg on fumed silica for biocatalysis in hexane ${ }^{22}$. This previous work is here extended to immobilization of the hydrolase CALB on fumed silica. CALB is an attractive enzyme for enzymatic catalysis in solvents $3,4,37,44-48$. Some aspects of the immobilization process and the physical characteristics of the immobilizate are discussed below before presenting results for enzymatic catalysis using the CALB/fumed silica immobilizate. 
Fumed silica is generally thought to consist of solid spherical primary particles (several $\mathrm{nm}$ diameter) formed by a flame hydrolysis process $24,25,49$. The primary particles fuse into necklace-like structures which then form entangled agglomerates with a size on the order of $100 \mathrm{~nm}$. Both the synthesis process and the resulting material are fundamentally different from silica gel ${ }^{49,50}$. A transmission electron micrograph of a CALB/fumed silica immobilizate reveals the expected size of the fumed silica aggregates (order of 100nm) with some indication of individual fumed silica particles in the expected necklace-like arrangement visible between the agglomerates (Fig. 4). A schematic rendition of a fumed silica agglomerate is also shown.

The initial interaction of CALB with fumed silica in aqueous suspension before freezing and lyophilization was explored by variation of the aqueous phase $\mathrm{pH}$ using different buffers. Enzyme adsorption was tracked by difference using the Bradford assay of the liquid phase. Typical kinetic adsorption data in aqueous solution are shown in Fig. 1. The data indicates that sorption equilibrium was reached or at least approached. Fig. 2 shows the combined end points of the adsorption experiments at different $\mathrm{pH}$ values. From 95 to $99 \mathrm{wt} \%$ fumed silica $(w t \%=100 *$ mass of fumed silica/(mass of fumed silica+mass of enzyme) ) the adsorption proceeds to the nominal surface coverage (indicated by the diagonal line), independent of $\mathrm{pH}$. The nominal surface coverage line was calculated by dividing the mass of enzyme by the nominal surface area of the mass of fumed silica weighed in as reported by the manufacturer. It appears that there are sufficient opportunities for all of the enzyme material to adsorb on the fumed silica, both below and above the isoelectric point of CALB as long as the silica surface area is abundant. When the surface area for interaction becomes more scarce, however (near $90 \mathrm{wt} \%$ fumed silica and below) the data seem to indicate that the strong expected electrostatic interaction between silica (negative) and enzyme (positive) below the isoelectric point becomes 
more important. This leads to lower adsorption above the isoelectric $\mathrm{pH}$ when the fumed silica area is scarcer. This situation is schematically shown in Fig. 3. The catalytic experiments reported below were all performed with immobilizates originating from aqueous solution at $\mathrm{pH}$ 7.8 .

The question of how the enzyme is distributed on the fumed silica surfaces can be investigated using laser confocal microscopy of the immobilizate in hexane. The more uniform appearance in Fig. 5 panel A compared to the more clustered appearance in panel B reflects our experience that the dispersion of the fumed silica/enzyme immobilizate in hexane is more uniform for preparations at higher $\mathrm{wt} \%$ fumed silica likely due to the surface properties of silica being more prominent at high $\mathrm{wt} \%$ fumed silica. The roughly doubled surface intensities from $99 \mathrm{wt} \%$ fumed silica to $98.5 \mathrm{wt} \%$ fumed silica (Fig. 5 panel A1 vs. panel B1) correspond to a theoretical estimate of an increased in surface loading (mg enzyme $/ \mathrm{m}^{2}$ fumed silica) of $34 \%$ when assuming the nominal surface area of fumed silica, and a known size of CALB (all protein assumed as CALB ${ }^{51}$ ). The reasonable correlation of the predicted increase in surface loading from simple mass balance and physical size of the molecule vs. the available nominal area, and the direct evidence by confocal microscopy also confirms that the enzyme largely remains with the immobilizate and is not lost elsewhere.

The catalytic performance of our CALB/fumed silica preparations was first successfully benchmarked against our previous work with CALB where we used Novozym $435^{7}$ (data not shown).

The catalytic activity of $\mathrm{CALB} /$ fumed silica preparations significantly increased as the fumed silica content approached $90 \mathrm{wt} \%$ (Fig. 7). Our preparations approach the commercial Novozym 435 on an equivalent PLU basis. However, while the catalytic activity for $s$. Carlsberg 
immobilized on fumed silica in our previous work ${ }^{22}$ slowly increased further and essentially leveled off when even more fumed silica surface area was available for adsorption we found a precipitous drop in the activity for CALB at high fumed silica content. We successfully replicated this surprising result at high fumed silica content by testing two additional batches of each $w t \%$ fumed silica referred to as first and second replicas in Fig. 7. The possibility of mass transfer limitations causing the drop in activity at high fumed silica content was excluded through a reference test with $1 / 3$ of the CALB/fumed silica preparation in the same amount of solution. The activity was not substantially different suggesting that mass transfer limitations are likely not responsible for the drop in catalytic activity at high fumed silica content. We therefore conclude that the steep drop in catalytic activity at high fumed silica content for CALB preparations is indeed a real phenomenon that highlights the subtle differences between different enzymes even when they are immobilized with identical procedures on the same solid support. A possible rationale for the somewhat counterintuitive activity decrease as abundant area becomes available for enzyme immobilization is attempted below.

According to Gun'ko et al. ${ }^{32}$, the adsorption of proteins (e.g., Bovine Serum Albumin) on fumed silica in aqueous suspensions has many intricacies and depends on the morphology of the fumed silica, the protein type and concentration, $\mathrm{pH}$, ionic strength, and fumed silica concentration, among other parameters. To form the preparations at the various $w t \%$ of fumed silica shown here, a rapidly increasing amount of fumed silica was required (Table 1). Prior to lyophilization, the area of fumed silica per mass of protein (enzyme plus any inactive proteins in our purchased crude enzyme) available for adsorption is significantly larger at high wt $\%$ of fumed silica. One might speculate that above $90 \mathrm{wt} \%$ fumed silica, the probability of strong surface/protein interactions as opposed to protein-protein interactions significantly increases. 
Confinement of the enzyme molecules by multipoint attachment of the enzyme to the fumed silica surface (for example in the "neck" regions of the fused spherical primary silica particle necklaces) may lead to detrimental structural changes of the enzyme. Enzyme molecules may also deactivate simply by strong interaction with silica at high silica surface availability.

Recently, Gross and coworkers have physically adsorbed CALB on a series of macroporous polymeric supports and have investigated catalytic activity in ring opening polymerizations and polycondensations in organic solvents ${ }^{39-41}$. Gross et al. suggested that CALB molecules adsorbed in a more close-packed configuration are more likely to preserve their native structure and catalytic activity then when CALB molecules are adsorbed widely separated from one another ${ }^{39,}{ }^{40}$. In agreement with our findings, Gross et al. demonstrated that an intermediate enzyme loading can be found where no further improvement in activity is detected when more support material is provided per unit mass of enzyme. Their data suggest that this optimum enzyme/support ratio is highly dependent on the surface chemistry and morphology of the adsorbent. This research group has also reported that CALB molecules spread upon adsorption on their supports as has been suggested elsewhere for "soft" proteins ${ }^{52}$. This effect is likely to be accentuated when excessive area is available for adsorption supporting the notion that structural changes are promoted at high wt $\%$ fumed silica in our preparations.

To benchmark our best preparations against Novozym 435 we compared the apparent kinetic constants $K_{m}$ (ability to bind substrate) and $V_{m}$ (max. rate of reaction with sufficient substrate) as well as the catalytic efficiency $\left(V_{m} / K_{m}\right)$ (Table 2$)^{53}$. The catalytic efficiency for our $90 \mathrm{wt} \%$ fumed silica preparation and Novozym $435 \AA$ are of the same order of magnitude. In addition, Table 2 shows that the catalytic efficiency of our $90 \mathrm{wt} \%$ fumed silica preparation was about $90 \%$ higher compared to $10 \mathrm{wt} \%$ fumed silica. This confirms the crucial role of fumed silica 
availability relative to adsorbing enzyme in enhancing the catalytic activity of the enzyme. The effectiveness factor (the ratio of the observed reaction rate and the reaction rate absent all diffusional limitations) is also shown in Table 2. The effectiveness factors for our preparations approach unity. This demonstrates the absence of diffusion limitations for adsorbed enzyme on the non-porous fumed silica nanoparticle aggregates. CALB molecules are confined to particle surfaces where their exposure to substrate molecules is maximized. In contrast, Novozym 435 shows an effectiveness factor of 0.2 likely due to diffusion limitations in the confined spaces of the porous support beads.

Error! Not a valid bookmark self-reference. shows the catalytic activity of our preparations up to $70^{\circ} \mathrm{C}$. As the temperature is increased from $30^{\circ} \mathrm{C}$ to $40^{\circ} \mathrm{C}$ an Arrhenius-type activation is observed for all preparations. A clear and increasing loss of activity is however detected at $55^{\circ} \mathrm{C}$ and above. The $99 \mathrm{wt} \%$ fumed silica preparation is still somewhat active at $70^{\circ} \mathrm{C}$ where the other fumed silica preparations are almost completely deactivated. This appears consistent with the stabilization of adsorbed enzymes by solid supports ${ }^{33,54}$. The catalytic activity of Novozym 435 up to $70^{\circ} \mathrm{C}$ is also shown. A similar Arrhenius-type activation is observed but Novozym 435 is significantly more temperature stable than our preparations.

Fig. 9 shows the initial reaction rates of our preparations in hexane up to four days. For comparison, the results for Novozym 435 are superimposed. The activity of the fumed silica preparations declines quickly in the first $24 \mathrm{~h}$ and about $50 \%$ of the initial activity remains after 4 days of incubation while Novozym 435 retained about $60 \%$. The data point at 48 hours for Novozym 435 is likely impacted by random error. The significant initial loss of activity has been attributed by others to events at the active site of the enzyme molecule, including the breakdown of the acid-base catalytic properties and changes in the protonation state of the involved residues 
55. Gross et al. have recently speculated on desorption of the enzyme as a contributing cause of deactivation as seen in Fig. $9^{41}$.

The residual activity of our lyophilized preparations after 6 months of storage $\left(4^{\circ} \mathrm{C}\right.$, closed container) is shown in Fig. 10 along with data for fresh preparations. The $99 \mathrm{wt} \%$ fumed silica maintained the same albeit low level of activity. This can be seen to support the stabilization due to the enzyme/support interactions discussed above.

\section{Conclusions}

We have extended our recently developed procedure (lyophilization in presence of fumed silica) to immobilize enzymes on fumed silica for catalysis in hexane from s. Carlsberg to Candida antarctica Lipase B (CALB). Adjustment of the aqueous $\mathrm{pH}$ relative to the isoelectric point of CALB (pre-lyophilization) at low fumed silica surface availability can reduce the adsorption of the enzyme on fumed silica likely due to a change in surface charge of the enzyme. The impact of pre-lyophilization $\mathrm{pH}$ adjustment is not significant for adsorption at high surface area availability.

The catalytic activity of our best CALB/fumed silica preparation approached the commercially available biocatalyst Novozym 435®. The surprising decrease of catalytic activity of our preparations at very high fumed silica content was confirmed by multiple reproductions and reference tests since our previous experience with s. Carlsberg showed no sign of this. An "optimum" surface coverage may be hypothesized to be due to excessive or multipoint enzyme/fumed silica interactions at high fumed silica surface availability leading to denaturation as has been proposed by Gross and co-workers ${ }^{39,40}$. This could be enzyme specific as our previous results with $s$. Carlsberg indicate. We confirmed that CALB is activated when the temperature is increased up to $55^{\circ} \mathrm{C}$ as has been observed for other enzymes. A clear loss of 
activity is observed at even higher temperatures. The fumed silica preparation with the highest fumed silica content $(99 \mathrm{wt} \%)$ is the most temperature-stable and shows the best long term stability while showing overall lower activity than our best (90wt\%) preparations. This supports the argument of enhanced enzyme-fumed silica interactions at high fumed silica surface availability which may deactivate some enzyme molecules but confers stability on those still catalytically competent.

\section{References}

1. Klibanov, A. M., Improving enzymes by using them in organic solvents. Nature 2001, 409, (6817), 241-246.

2. Hudson, E. P.; Eppler, R. K.; Clark, D. S., Biocatalysis in semi-aqueous and nearly anhydrous conditions. Current Opinion in Biotechnology 2005, 16, (6), 637-643.

3. Gross, R. A.; Kumar, A.; Kalra, B., Polymer synthesis by in vitro enzyme catalysis. Chemical Reviews 2001, 101, (7), 2097-2124.

4. Gross, R. A.; Kalra, B., Biodegradable polymers for the environment. Science 2002, 297, (5582), 803-807.

5. Gotor, V., Biocatalysis applied to the preparation of pharmaceuticals. Organic Process Research \& Development 2002, 6, (4), 420-426.

6. Barahona, D.; Pfromm, P. H.; Rezac, M. E., Effect of water activity on the lipase catalyzed esterification of geraniol in ionic liquid [bmim]PF6. Biotechnology and Bioengineering 2006, 93, (2), 318-324.

7. $\quad$ Bartling, K.; Thompson, J. U. S.; Pfromm, P. H.; Czermak, P.; Rezac, M. E., Lipasecatalyzed synthesis of geranyl acetate in n-hexane with membrane-mediated water removal. Biotechnology and Bioengineering 2001, 75, (6), 676-681.

8. Bruno, F. F.; Akkara, J. A.; Ayyagari, M.; Kaplan, D. L.; Gross, R.; Swift, G.; Dordick, J. S., Enzymatic modification of insoluble amylose in organic solvents. Macromolecules 1995, 28, (26), 8881-8883.

9. Carrea, G.; Riva, S., Properties and synthetic applications of enzymes in organic solvents. Angewandte Chemie-International Edition 2000, 39, (13), 2226-2254.

10. Ghanem, A., The utility of cyclodextrins in lipase-catalyzed transesterification in organic solvents: enhanced reaction rate and enantioselectivity. Organic \& Biomolecular Chemistry 2003, 1, (8), 1282-1291.

11. Klibanov, A. M., Why are enzymes less active in organic solvents than in water? Trends in Biotechnology 1997, 15, (3), 97-101.

12. Persson, M.; Wehtje, E.; Adlercreutz, P., Factors governing the activity of lyophilised and immobilised lipase preparations in organic solvents. Chembiochem 2002, 3, (6), 566-571.

13. Long, J.; Hutcheon, G. A.; Cooper, A. I., Combinatorial discovery of reusable noncovalent supports for enzyme immobilization and nonaqueous catalysis. Journal of Combinatorial Chemistry 2007, 9, (3), 399-406. 
14. Sheldon, R. A.; Schoevaart, R.; Van Langen, L. M., Cross-linked enzyme aggregates (CLEAs): A novel and versatile method for enzyme immobilization (a review). Biocatalysis and Biotransformation 2005, 23, (3-4), 141-147.

15. Mine, Y.; Fukunaga, K.; Itoh, K.; Yoshimoto, M.; Nakao, K.; Sugimura, Y., Enhanced enzyme activity and enantioselectivity of lipases in organic solvents by crown ethers and cyclodextrins. Journal of Bioscience and Bioengineering 2003, 95, (5), 441-447.

16. Secundo, F.; Barletta, G. L.; Dumitriu, E.; Carrea, G., Can an inactivating agent increase enzyme activity in organic solvent? Effects of 18-crown-6 on lipase activity, enantioselectivity, and conformation. Biotechnology and Bioengineering 2007, 97, (1), 12-18.

17. Santos, A. M.; Vidal, M.; Pacheco, Y.; Frontera, J.; Baez, C.; Ornellas, O.; Barletta, G.; Griebenow, K., Effect of crown ethers on structure, stability, activity, and enantioselectivity of subtilisin Carlsberg in organic solvents. Biotechnology and Bioengineering 2001, 74, (4), 295308.

18. Lindsay, J. P.; Clark, D. S.; Dordick, J. S., Penicillin amidase is activated for use in nonaqueous media by lyophilizing in the presence of potassium chloride. Enzyme and Microbial Technology 2002, 31, (3), 193-197.

19. Lindsay, J. P.; Clark, D. S.; Dordick, J. S., Combinatorial formulation of biocatalyst preparations for increased activity in organic solvents: Salt activation of penicillin amidase. Biotechnology and Bioengineering 2004, 85, (5), 553-560.

20. Ru, M. T.; Hirokane, S. Y.; Lo, A. S.; Dordick, J. S.; Reimer, J. A.; Clark, D. S., On the salt-induced activation of lyophilized enzymes in organic solvents: Effect of salt kosmotropicity on enzyme activity. Journal of the American Chemical Society 2000, 122, (8), 1565-1571.

21. Ru, M. T.; Wu, K. C.; Lindsay, J. P.; Dordick, J. S.; Reimer, J. A.; Clark, D. S., Towards more active biocatalysts in organic media: Increasing the activity of salt-activated enzymes. Biotechnology and Bioengineering 2001, 75, (2), 187-196.

22. Wurges, K.; Pfromm, P. H.; Rezac, M. E.; Czermak, P., Activation of subtilisin Carlsberg in hexane by lyophilization in the presence of fumed silica. Journal of Molecular Catalysis BEnzymatic 2005, 34, (1-6), 18-24.

23. Pfromm, P. H.; Rezac, M. E.; Wurges, K.; Czermak, P., Fumed silica activated subtilisin Carlsberg in hexane in a packed-bed reactor. Aiche Journal 2007, 53, (1), 237-242.

24. Gun'ko, V. M.; Mironyuk, I. F.; Zarko, V. I.; Voronin, E. F.; Turov, V. V.; Pakhlov, E. M.; Goncharuk, E. V.; Nychiporuk, Y. M.; Vlasova, N. N.; Gorbik, P. P.; Mishchuk, O. A.; Mishchuk, O. A.; Chuiko, A. A.; Kulik, T. V.; Palyanytsya, B. B.; Pakhovchishin, S. V.; Skubiszewska-Zieba, J.; Janusz, W.; Turov, A. V.; Leboda, R., Morphology and surface properties of fumed silicas. Journal of Colloid and Interface Science 2005, 289, (2), 427-445.

25. Gun'ko, V. M.; Mironyuk, I. F.; Zarko, V. I.; Turov, V. V.; Voronin, E. F.; Pakhlov, E. M.; Goncharuk, E. V.; Leboda, R.; Skubiszewska-Zieba, J.; Janusz, W.; Chibowski, S.; Levchuk, Y. N.; Klyueva, A. V., Fumed silicas possessing different morphology and hydrophilicity. Journal of Colloid and Interface Science 2001, 242, (1), 90-103.

26. Gun'ko, V. M.; Voronin, E. F.; Nosach, L. V.; Pakhlov, E. M.; Guzenko, N. V.; Leboda, R.; Skubiszewska-Zieba, J., Adsorption and migration of poly(vinyl pyrrolidone) at a fumed silica surface. Adsorption Science \& Technology 2006, 24, (2), 143-157.

27. Gun'ko, V. M.; Zarko, V. I.; Voronin, E. F.; Goncharuk, E. V.; Andriyko, L. S.; Guzenko, N. V.; Nosach, L. V.; Janusz, W., Successive interaction of pairs of soluble organics with nanosilica in aqueous media. Journal of Colloid and Interface Science 2006, 300, (1), 20-32. 
28. Gun'ko, V. M.; Zarko, V. I.; Voronin, E. F.; Turov, V. V.; Mironyuk, I. F.; Gerashchenko, II; Goncharuk, E. V.; Pakhlov, E. M.; Guzenko, N. V.; Leboda, R.; Skubiszewska-Zieba, J.; Janusz, W.; Chibowski, S.; Levchuk, Y. N.; Klyueva, A. V., Impact of some organics on structural and adsorptive characteristics of fumed silica in different media. Langmuir 2002, 18, (3), 581-596.

29. Mironyuk, I. F.; Gun'ko, V. M.; Turov, V. V.; Zarko, V. I.; Leboda, R.; SkubiszewskaZieba, J., Characterization of fumed silicas and their interaction with water and dissolved proteins. Colloids and Surfaces a-Physicochemical and Engineering Aspects 2001, 180, (1-2), 87-101.

30. Rugal, A. A.; Gun'ko, V. M.; Barvinchenko, V. N.; Turov, V. V.; Semeshkina, T. V.; Zarko, V. I., Interaction of fibrinogen with nanosilica. Central European Journal of Chemistry 2007, 5, (1), 32-54.

31. Voronin, E. F.; Gun'ko, V. M.; Guzenko, N. V.; Pakhlov, E. M.; Nosach, L. V.; Leboda, R.; Skubiszewska-Zieba, J.; Malysheva, M. L.; Borysenko, M. V.; Chuiko, A. A., Interaction of poly(ethylene oxide) with fumed silica. Journal of Colloid and Interface Science 2004, 279, (2), 326-340.

32. Gun'ko, V. M.; Mikhailova, I. V.; Zarko, V. I.; Gerashchenko, II; Guzenko, N. V.; Janusz, W.; Leboda, R.; Chibowski, S., Study of interaction of proteins with fumed silica in aqueous suspensions by adsorption and photon correlation spectroscopy methods. Journal of Colloid and Interface Science 2003, 260, (1), 56-69.

33. Unsworth, L. D.; van der Oost, J.; Koutsopoulos, S., Hyperthermophilic enzymes stability, activity and implementation strategies for high temperature applications. Febs Journal 2007, 274, (16), 4044-4056.

34. Norde, W., Driving forces for protein adsorption at solid surfaces. In Biopolymers at Interfaces, 2nd edn ed.; Marcel Dekker, Inc.: New York, 2003.

35. Barrias, C. C.; Martins, C. L.; Miranda, C. S.; Barbosa, M. A., Adsorption of a therapeutic enzyme to self-assembled monolayers: effect of surface chemistry and solution $\mathrm{pH}$ on the amount and activity of adsorbed enzyme. Biomaterials 2005, 26, (15), 2695-2704.

36. Ghanem, A., Trends in lipase-catalyzed asymmetric access to enantiomerically pure/enriched compounds. Tetrahedron 2007, 63, (8), 1721-1754.

37. Anderson, E. M.; Karin, M.; Kirk, O., One biocatalyst - Many applications: The use of Candida antarctica B-lipase in organic synthesis. Biocatalysis and Biotransformation 1998, 16, (3), 181-204.

38. Schmid, R. D.; Verger, R., Lipases: Interfacial enzymes with attractive applications. Angewandte Chemie-International Edition 1998, 37, (12), 1609-1633.

39. Chen, B.; Miller, M. E.; Gross, R. A., Effects of porous polystyrene resin parameters on Candida antarctica Lipase B adsorption, distribution, and polyester synthesis activity. Langmuir 2007, 23, (11), 6467-6474.

40. Chen, B.; Miller, E. M.; Miller, L.; Maikner, J. J.; Gross, R. A., Effects of macroporous resin size on Candida antarctica lipase B adsorption, fraction of active molecules, and catalytic activity for polyester synthesis. Langmuir 2007, 23, (3), 1381-1387.

41. Chen, B.; Hu, J.; Miller, E. M.; Xie, W. C.; Cai, M. M.; Gross, R. A., Candida antarctica lipase B chemically immobilized on epoxy-activated micro- and nanobeads: Catalysts for polyester synthesis. Biomacromolecules 2008, 9, (2), 463-471. 
42. Kang, I. J.; Pfromm, P. H.; Rezac, M. E., Real time measurement and control of thermodynamic water activities for enzymatic catalysis in hexane. Journal of Biotechnology 2005, 119, (2), 147-154.

43. Bradford, M. M., Rapid and Sensitive Method for Quantitation of Microgram Quantities of Protein Utilizing Principle of Protein-Dye Binding. Analytical Biochemistry 1976, 72, (1-2), 248-254.

44. Houde, A.; Kademi, A.; Leblanc, D., Lipases and their industrial applications - An overview. Applied Biochemistry and Biotechnology 2004, 118, (1-3), 155-170.

45. Kirk, O.; Christensen, M. W., Lipases from Candida antarctica: Unique biocatalysts from a unique origin. Organic Process Research \& Development 2002, 6, (4), 446-451.

46. Kobayashi, T.; Adachi, S., Reaction equilibrium for lipase-catalyzed condensation in organic solvent systems. Biotechnology Letters 2004, 26, (19), 1461-1468.

47. Lutz, S., Engineering lipase B from Candida antarctica. Tetrahedron-Asymmetry 2004, $15,(18), 2743-2748$.

48. Plou, F. J.; Cruces, M. A.; Ferrer, M.; Fuentes, G.; Pastor, E.; Bernabe, M.; Christensen, M.; Comelles, F.; Parra, J. L.; Ballesteros, A., Enzymatic acylation of di- and trisaccharides with fatty acids: choosing the appropriate enzyme, support and solvent. Journal of Biotechnology 2002, 96, (1), 55-66.

49. Iler, R. K., The Chemistry of Silica. John Wiley \& Sons, Inc.: 1979; p 896.

50. Barthel, H.; Heinemann, M.; Stintz, M.; Wessely, B., Particle sizes of fumed silica. Particle \& Particle Systems Characterization 1999, 16, (4), 169-176.

51. Sate, D.; Janssen, M. H. A.; Stephens, G.; Sheldon, R. A.; Seddon, K. R.; Lu, J. R., Enzyme aggregation in ionic liquids studied by dynamic light scattering and small angle neutron scattering. Green Chemistry 2007, 9, (8), 859-867.

52. Koutsopoulos, S.; van der Oost, J.; Norde, W., Structural features of a hyperthermostable endo-beta-1,3-glucanase in solution and adsorbed on "invisible" particles. Biophysical Journal 2005, 88, (1), 467-474.

53. Shuler, M. L.; Kargi, F., Bioprocess engineering : basic concepts. Second ed.; Upper Saddle River: New Jersey, 2002; p 66-67.

54. Bailey, J. E.; Ollis., D. F., Biochemical engineering fundamentals Second ed.; McGrawHill: New York 1986.

55. Castillo, B.; Pacheco, Y.; Al-Azzam, W.; Griebenow, K.; Devi, M.; Ferrer, A.; Barletta, G., On the activity loss of hydrolases in organic solvents - I. Rapid loss of activity of a variety of enzymes and formulations in a range of organic solvents. Journal of Molecular Catalysis BEnzymatic 2005, 35, (4-6), 147-153. 


\section{Table 1}

Summary of the amounts of fumed silica and buffer employed for the various enzyme preparations. For all cases, the amount of crude CALB was $6.25 \mathrm{mg}$

\begin{tabular}{|c|c|c|c|c|}
\hline $\begin{array}{c}\text { Target Preparation } \\
\text { wt } \% \\
\text { Fumed Silica* }\end{array}$ & $\begin{array}{l}\text { Aqueous } \\
\text { Buffer } \\
\text { (ml) }\end{array}$ & $\begin{array}{c}\text { Fumed silica } \dagger \\
\text { (mg) }\end{array}$ & $\begin{array}{c}\text { Enzyme } \\
\text { Concentration } \\
(\mathrm{mg} / \mathrm{ml})\end{array}$ & $\begin{array}{c}\text { Amount of } \\
\text { preparation } \\
\text { containing } 35 \mathrm{U} \\
\text { (mg of lyophilized } \\
\text { preparation) }\end{array}$ \\
\hline $\mathbf{0 . 0}$ & 0.9 & 0.0 & 6.6 & 1.3 \\
\hline 10.0 & 1.1 & 0.7 & 6.0 & 1.4 \\
\hline 30.0 & 1.4 & 2.7 & 4.6 & 1.8 \\
\hline 50.0 & 1.9 & 6.3 & 3.3 & 2.5 \\
\hline 90.0 & 9.4 & 56.3 & 0.7 & 12.5 \\
\hline 95.0 & 18.8 & 118.8 & 0.3 & 25.0 \\
\hline 98.5 & 62.5 & 410.0 & 0.1 & 83.3 \\
\hline 99.0 & 62.5 & 618.8 & 0.1 & 125.0 \\
\hline Novozym $435 \circledR$ & - & - & - & 5.0 \\
\hline
\end{tabular}

* The $\mathrm{wt} \% \mathrm{FS}$ was calculated as follows:

$$
w t \% F S=m g F S /(m g F S+m g C A L B)
$$

$\uparrow$ The required mass of fumed silica is computed according to:

$$
m g F S=(w t \% F S * m g C A L B) /(100-w t \% F S)
$$

where $m g F S$ are the miligrams of fumed silica and $m g C A L B$ the miligrams of crude CALB. 
Table 2

Apparent kinetic constants and catalytic efficiency of CALB co-lyophilized with fumed silica (FS) compared to Novozym 435®

\begin{tabular}{|c|c|c|c|c|}
\hline Preparation & $\begin{array}{c}V_{m G} \\
\left(\mu \mathrm{mol}_{\mathrm{GerAc}} / \mathrm{min}\right)\end{array}$ & $K_{m G}(\mathrm{mM})$ & $\begin{array}{c}\text { Catalytic efficiency } \\
V_{m G} / K_{\mathrm{mG}} \\
\left(\mu \mathrm{mol}_{\mathrm{GerAc}} \mathrm{min}^{-1} \mathrm{mM}^{-1}\right)\end{array}$ & $\begin{array}{c}\text { Effectiveness } \\
\text { factor } \\
\eta\end{array}$ \\
\hline $10 \mathrm{wt} \% \mathrm{FS}$ & 0.3 & 238 & 0.0014 & 0.9998 \\
\hline $30 \mathrm{wt} \% \mathrm{FS}$ & 3.6 & 781 & 0.0046 & 0.9614 \\
\hline $50 \mathrm{wt} \% \mathrm{FS}$ & 1.5 & 245 & 0.0063 & 0.9951 \\
\hline $90 \mathrm{wt} \% \mathrm{FS}$ & 1.8 & 161 & 0.0114 & 0.9928 \\
\hline Novozym 435® & 2.7 & 204 & 0.0134 & 0.2144 \\
\hline
\end{tabular}




\section{Figures}




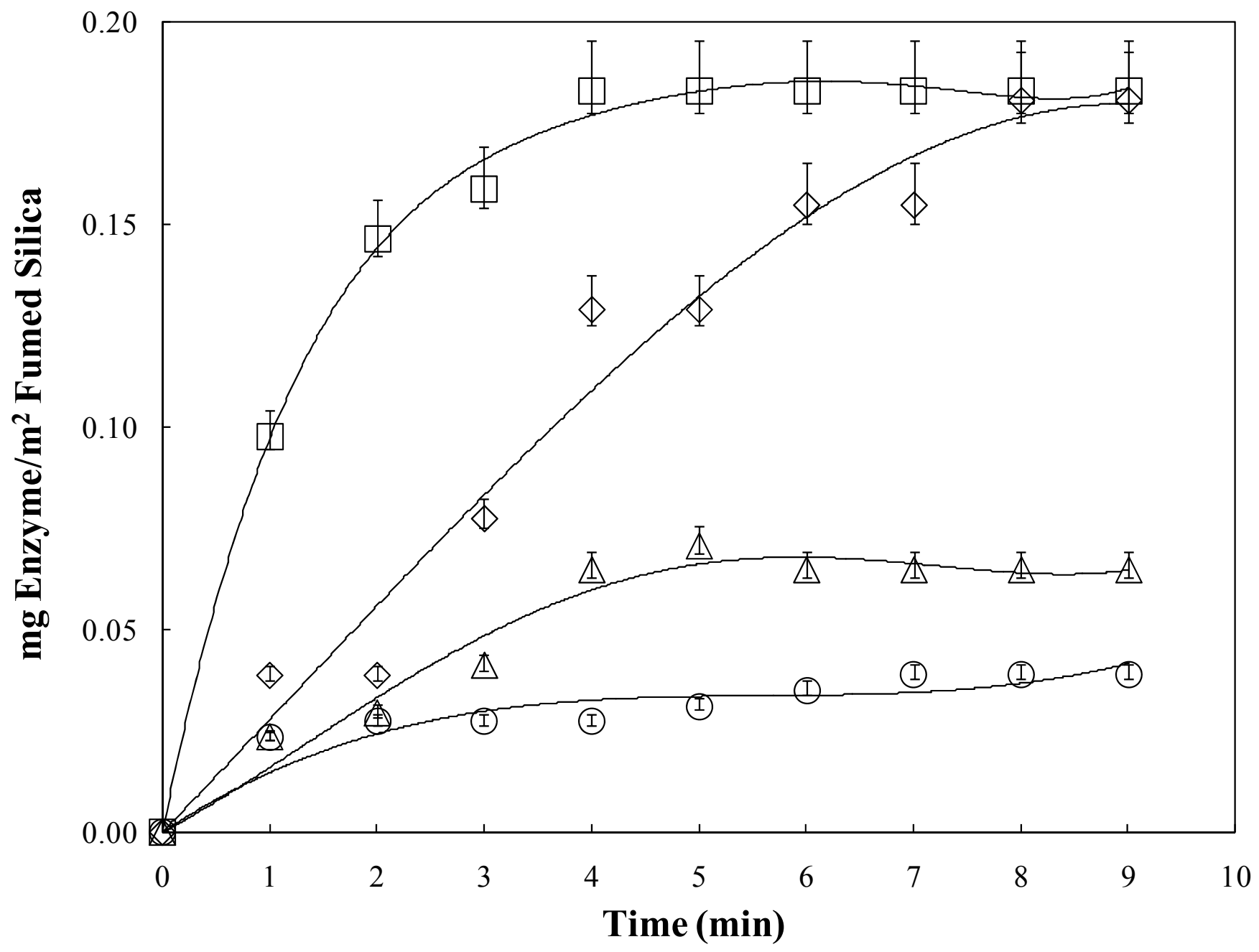

Fig. 1. Adsorption kinetics of CALB on fumed silica in aqueous suspensions at pH7.8 (phosphate buffer, $0.1 \mathrm{M} ; 25^{\circ} \mathrm{C}$ ). Fumed silica contents: $(\diamond) 90 \mathrm{wt} \% \mathrm{FS},(\square) 95 \mathrm{wt} \% \mathrm{FS},(\Delta) 98.5 \mathrm{wt} \% \mathrm{FS},(\circ) 99 \mathrm{wt} \% \mathrm{FS}$ (y-error bars represent the standard error of multiple analyses of identical samples). 


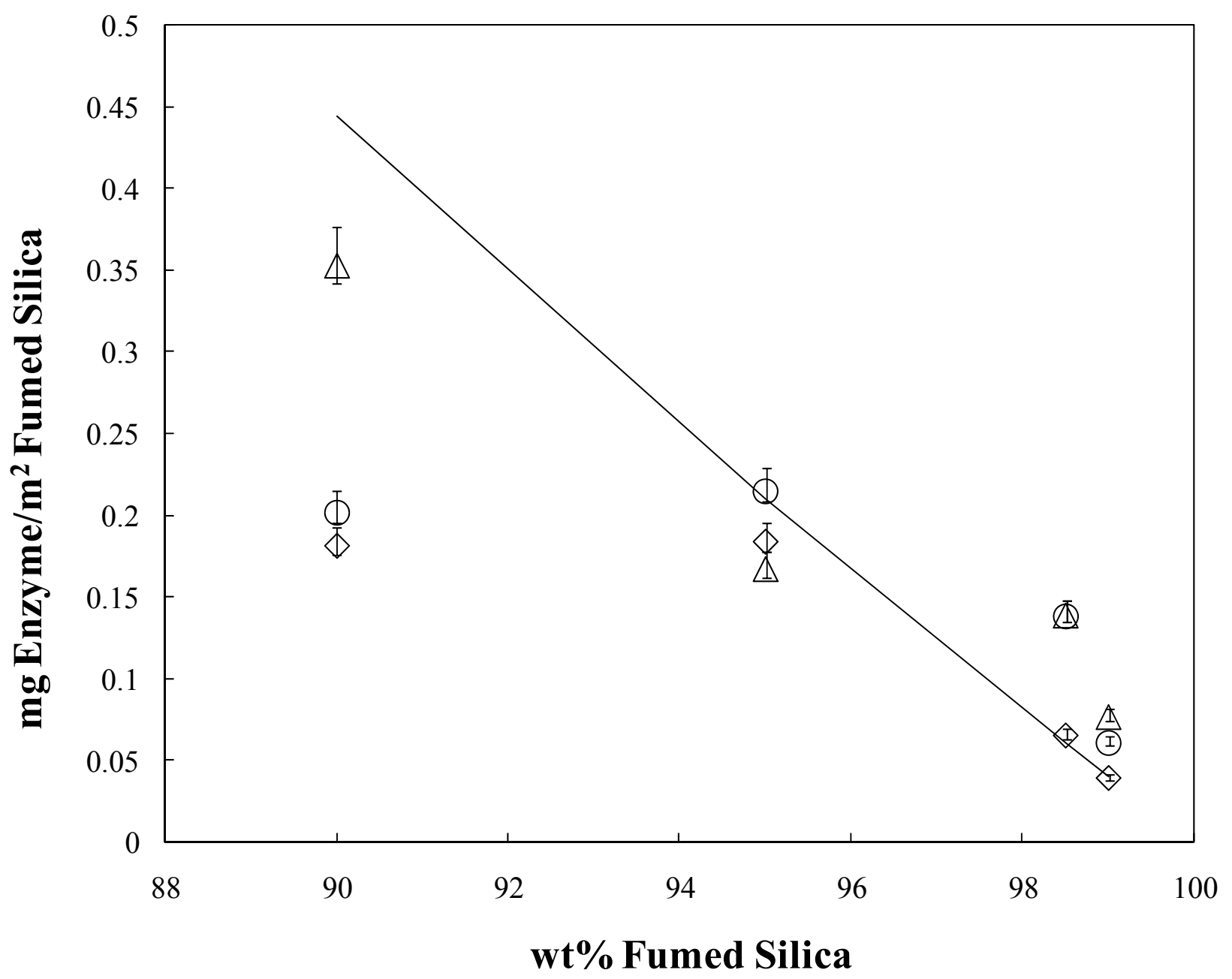

Fig. 2. Surface loading of fumed silica with enzyme at different $\mathrm{pH}$ values as a function of the fumed silica content in the starting materials. $(\Delta) \mathrm{pH}=4.0,(\diamond) \mathrm{pH}=7.8,(\circ) \mathrm{pH}=9.5$. Data obtained from the final steady-state of the adsorption kinetics experiments. The solid line is calculated by dividing the mass of enzyme weighed in by the nominal surface area of the fumed silica that was used. The impact of $\mathrm{pH}$ relative to the isoelectric point is only important at relatively low surface area availability (low wt\% fumed silica). 


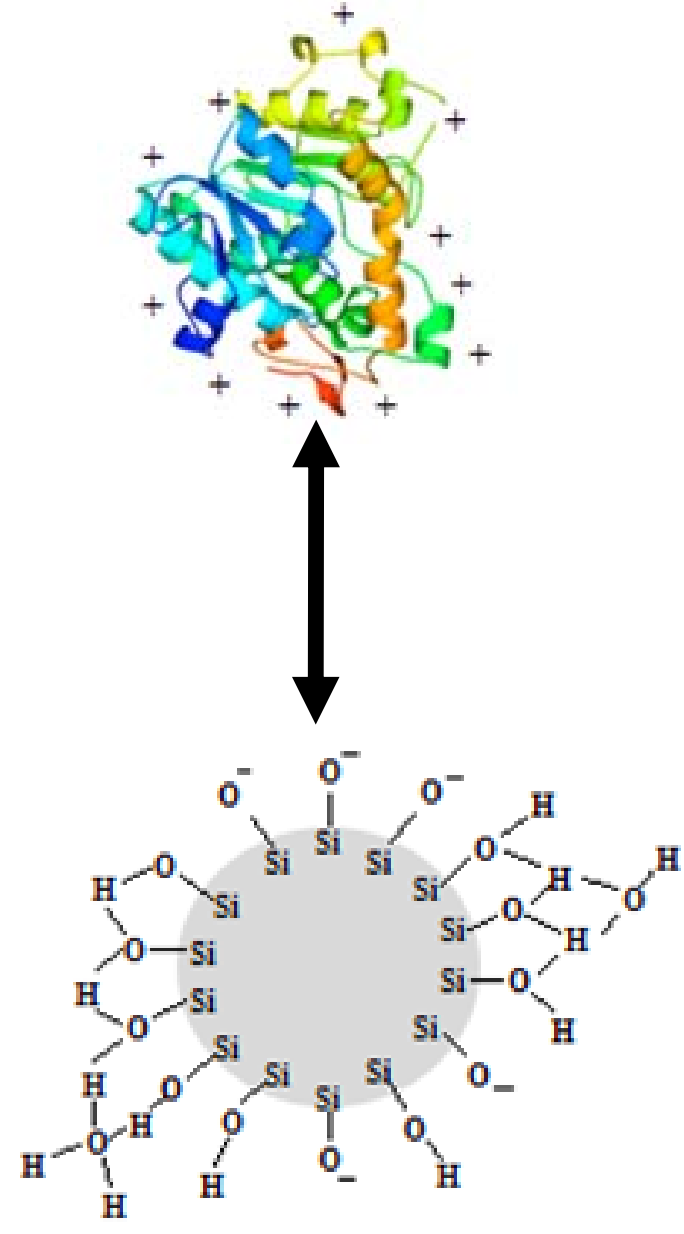

pH 4.0 (below pI)
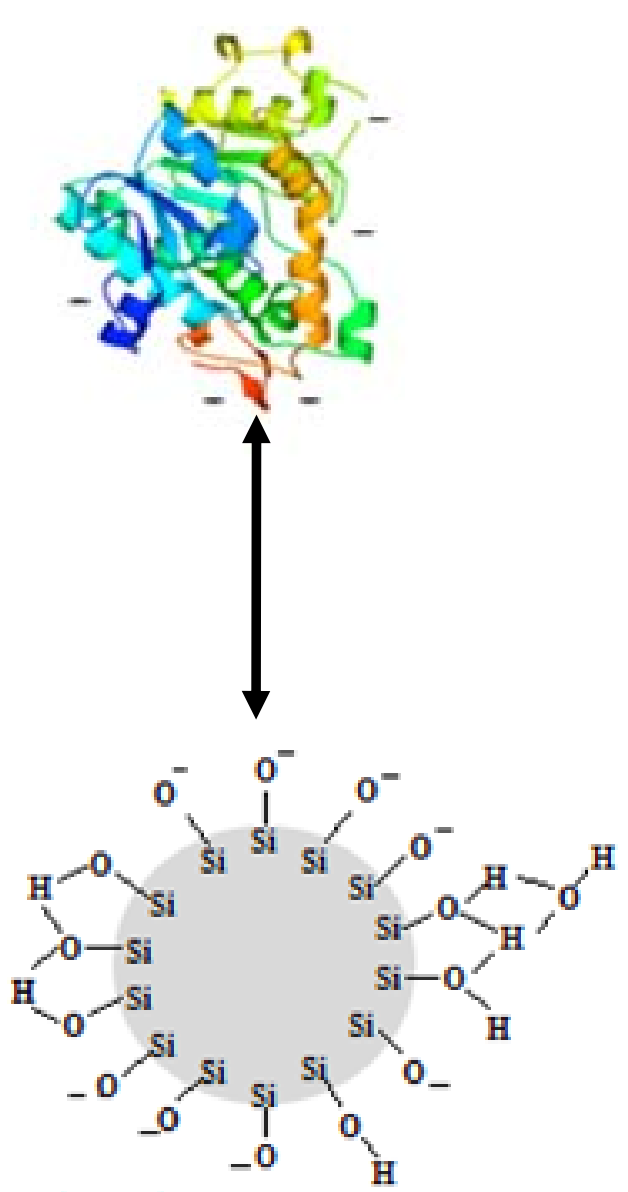

pH 7.8 (above pI)

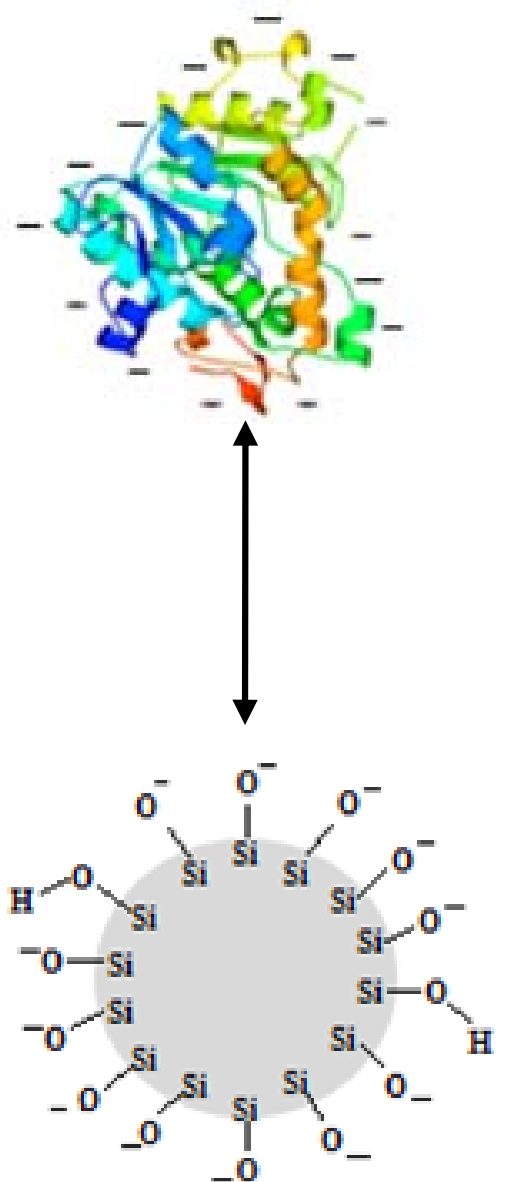

pH 9.5 (above pI)

Fig. 3. Schematic of surface charges for CALB and fumed silica nanoparticles in aqueous suspensions relative to the isoelectric point (pI). (Water molecules are not shown). Arrow widths illustrate the anticipated strength of the electrostatic interactions. 


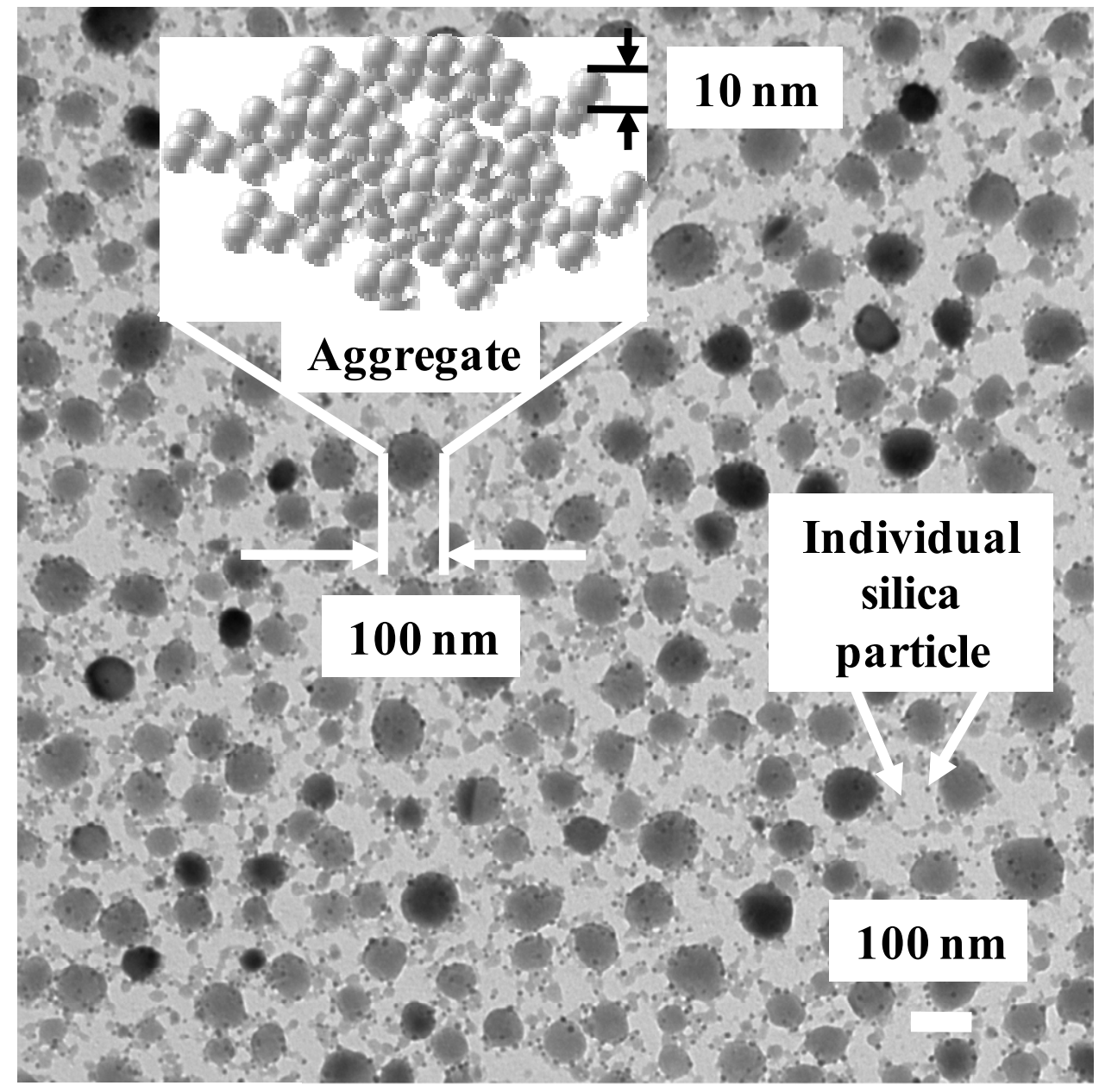

Fig. 4. Transmission Electron Microscopy (TEM) image and schematic representation of a typical lyophilized fumed silica/enzyme preparation. 

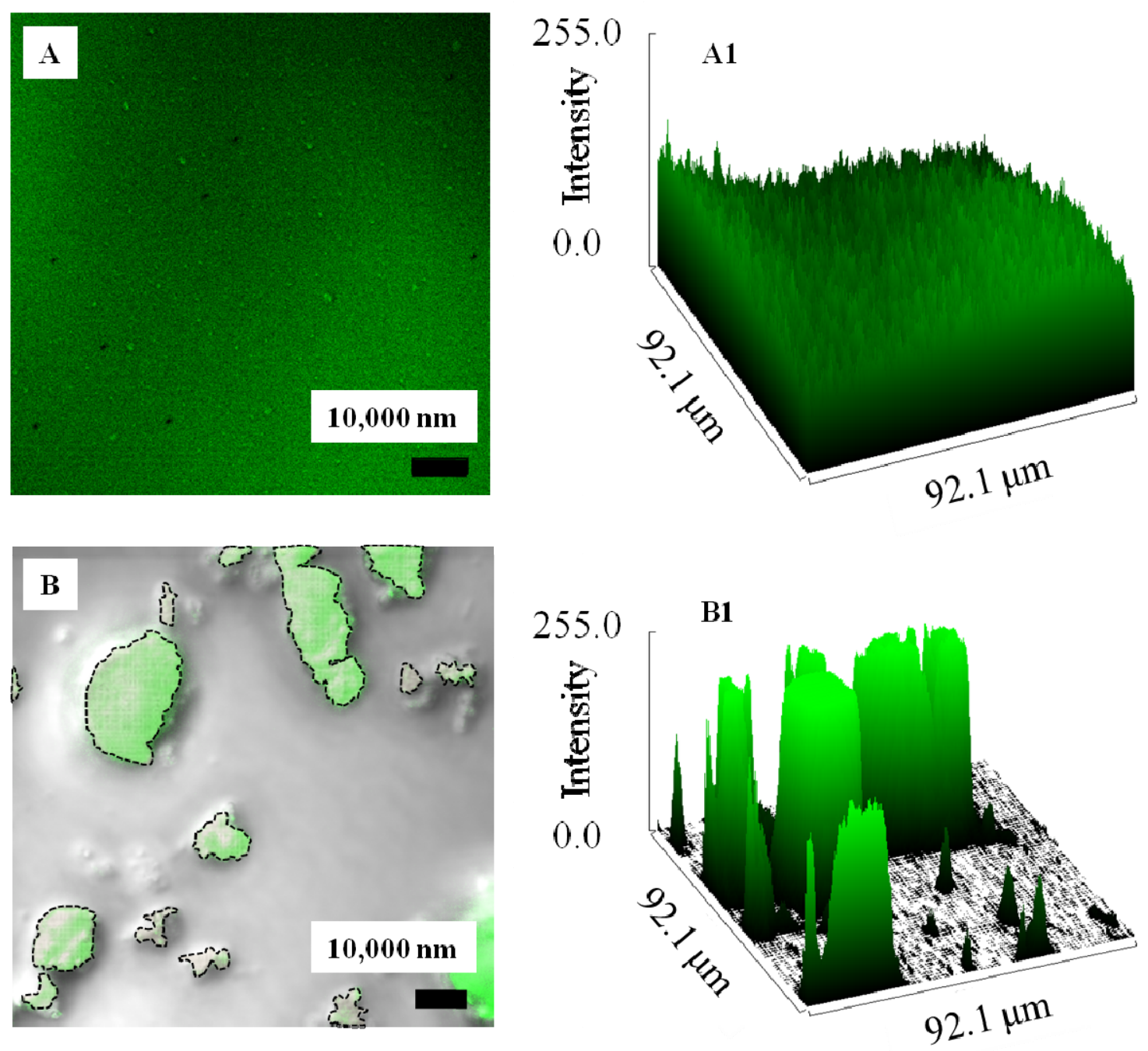

Fig. 5. Confocal images of the distribution of CALB immobilized on fumed silica (FS). (A) $99 \mathrm{wt} \%$ FS and (B) $98.5 \mathrm{wt} \%$ FS. The corresponding surface fluorescence intensities are shown in panels A1 and B1. The doubling of the intensity corresponds roughly to a doubling of the enzyme loading per area of fumed silica (Fig. 2, 98.5wt \% FS and $99 \mathrm{wt} \% \mathrm{FS}$, diamond symbols). The originally green fluorescence areas in panel B are emphasized by dashed contours. 


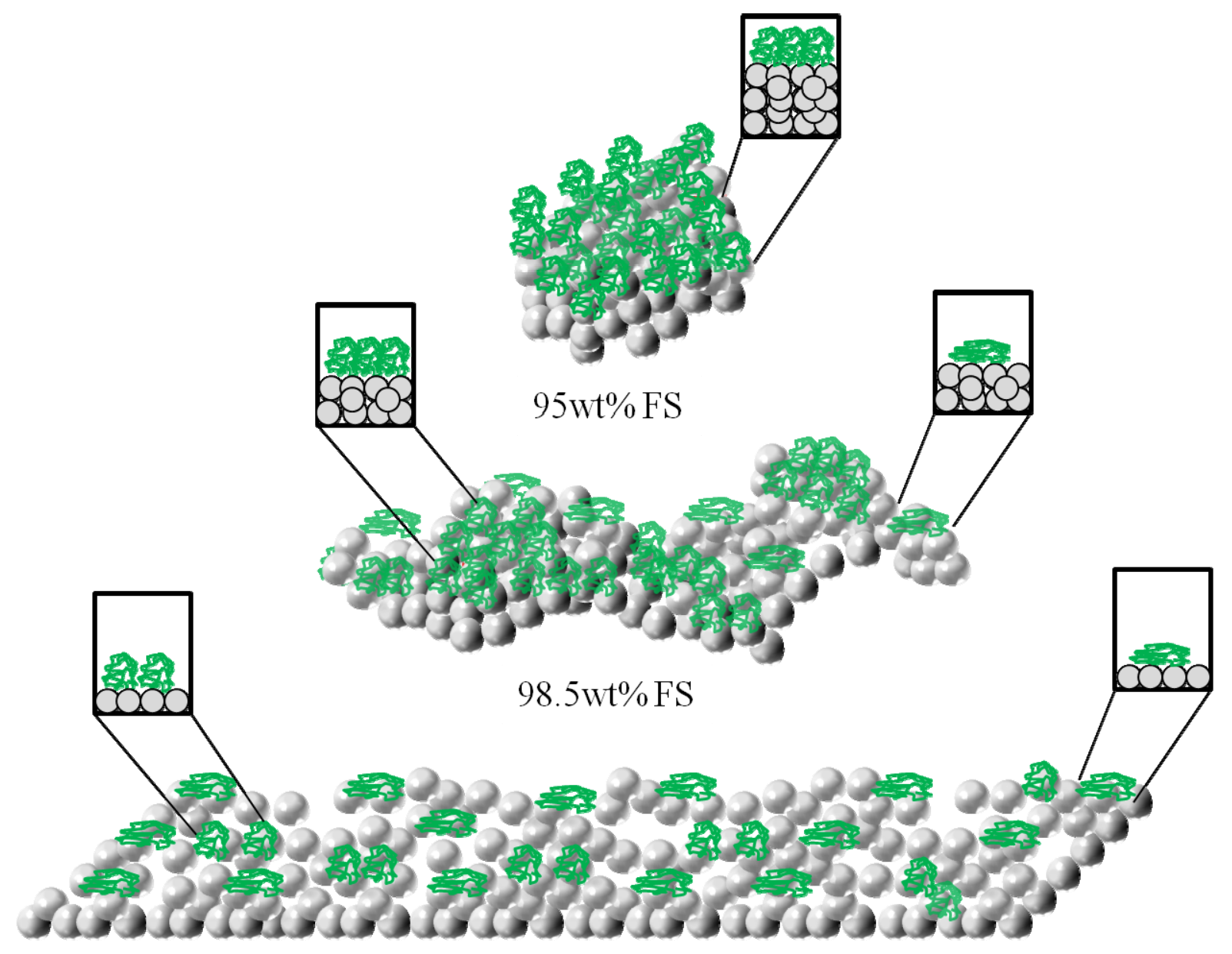

99wt $\%$ FS

Fig. 6. Schematic model for enzyme/fumed silica interactions at different surface loadings. The enzyme arrangement changes from a crowded surface to single molecule adsorption as the surface availability increases. The opportunity for maximum interaction of the enzyme with fumed silica perhaps enhanced by surface topography (availability of "neck" positions) may lead to detrimental deformation of the enzyme molecule. (Based on concepts put forth by Gross et al. ${ }^{39,40}$. The schematic is roughly to scale, primary fumed silica nanoparticle diameter $\sim 10 \mathrm{~nm}$; CALB molecular diameter $\sim 6 \mathrm{~nm}^{51}$ ). 


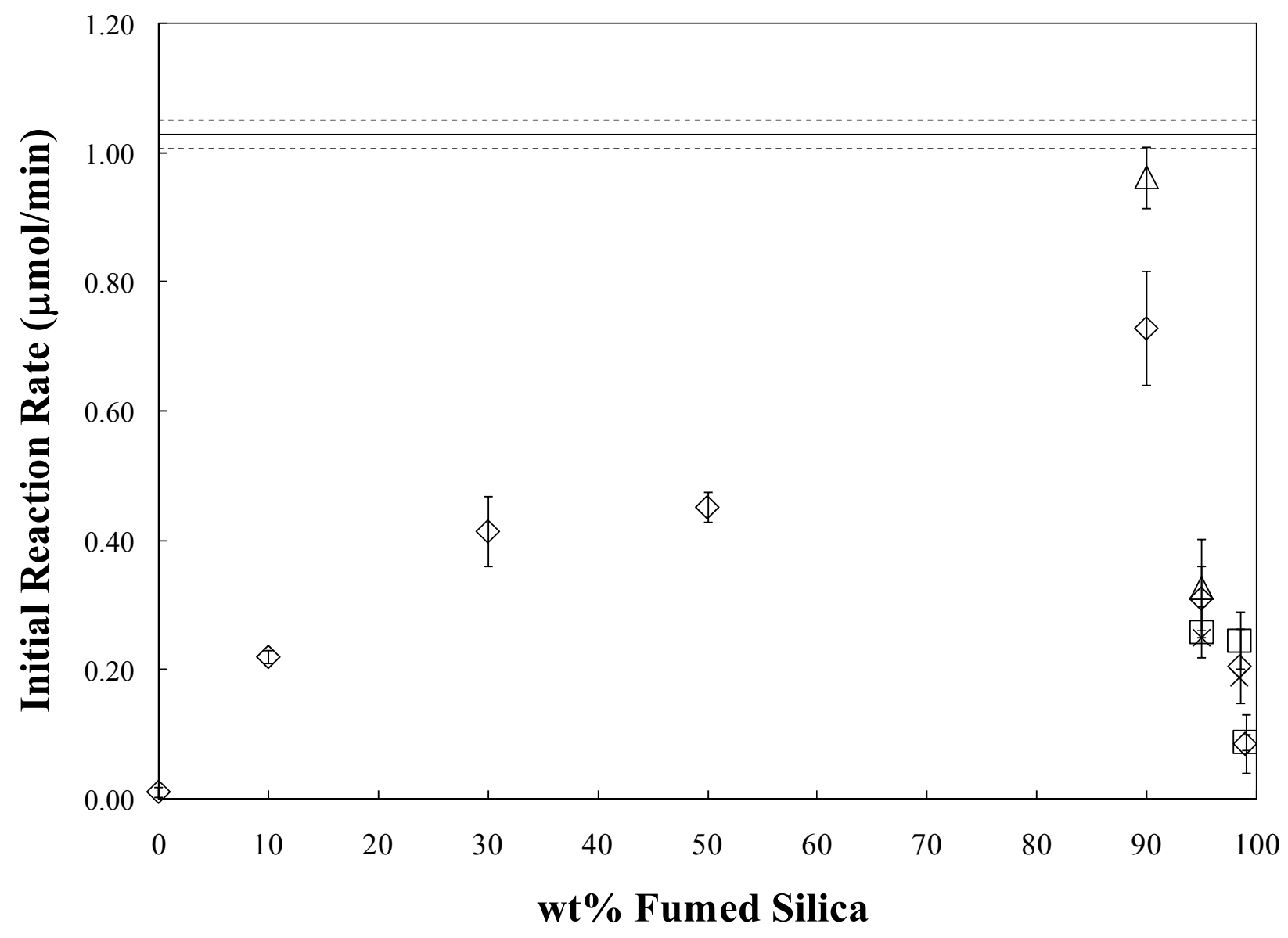

Fig. 7. Catalytic activity of CALB immobilized on fumed silica as a function of the fumed silica content in the preparation. Geraniol: $0.1 M .(\diamond)$ Experiments over the entire domain of concentrations. Experiments to confirm the surprising decrease in reaction rate at high fumed silica content: $(\Delta)$ first replica of $90 \mathrm{wt} . \%$ and $95 \mathrm{wt} . \%$ fumed silica, $(\square)$ second replica of $95 \mathrm{wt} . \%, 98.5 \mathrm{wt} . \%$ and 99 wt.\% fumed silica, $(\times)$ test to rule out mass transfer limitations, reaction volume $15 \mathrm{ml}, 95 \mathrm{wt} . \%$ and 98.5 wt. $\%$ fumed silica. Solid line represents Novozym $435 \AA$; dashed lines and y-error bars represent the cumulative standard error from the calculation of conversion and the linear assumption of the initial reaction rate. 


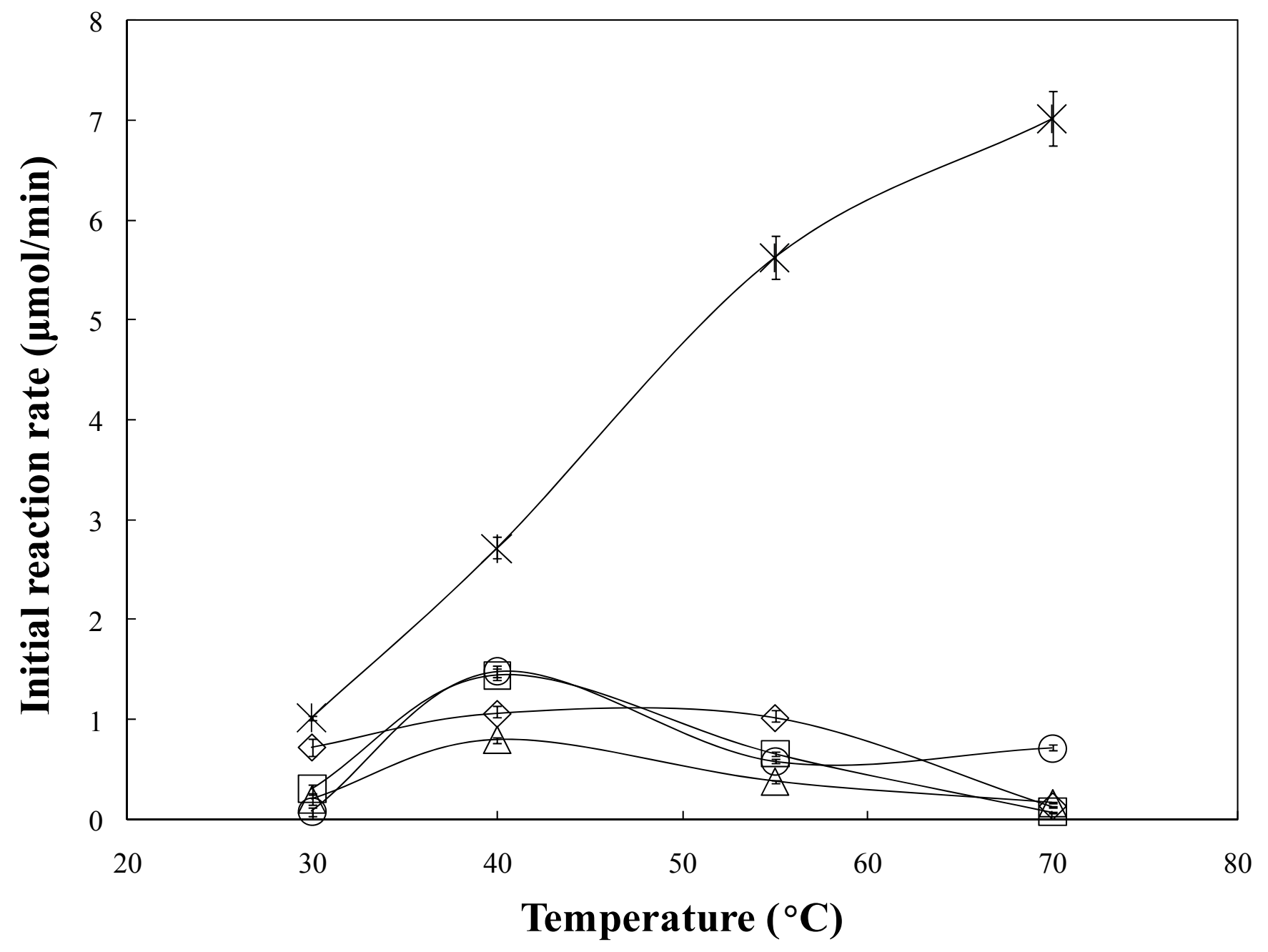

Fig. 8. Effect of temperature on the catalytic activity of CALB immobilized on fumed silica at various fumed silica (FS) contents. ( $\diamond)$ $90 \mathrm{wt} . \% \mathrm{FS},(\square) 95 \mathrm{wt} \%$ FS, ( $\Delta) 98.5 \mathrm{wt} \%$ FS, (০) 99 wt.\% FS. Effect of temperature on the catalytic activity of Novozym 435 (*) Solid lines added to guide the eye; y-error bars represent the cumulative standard error from the calculation of conversion and the linear assumption of the initial reaction rate. 


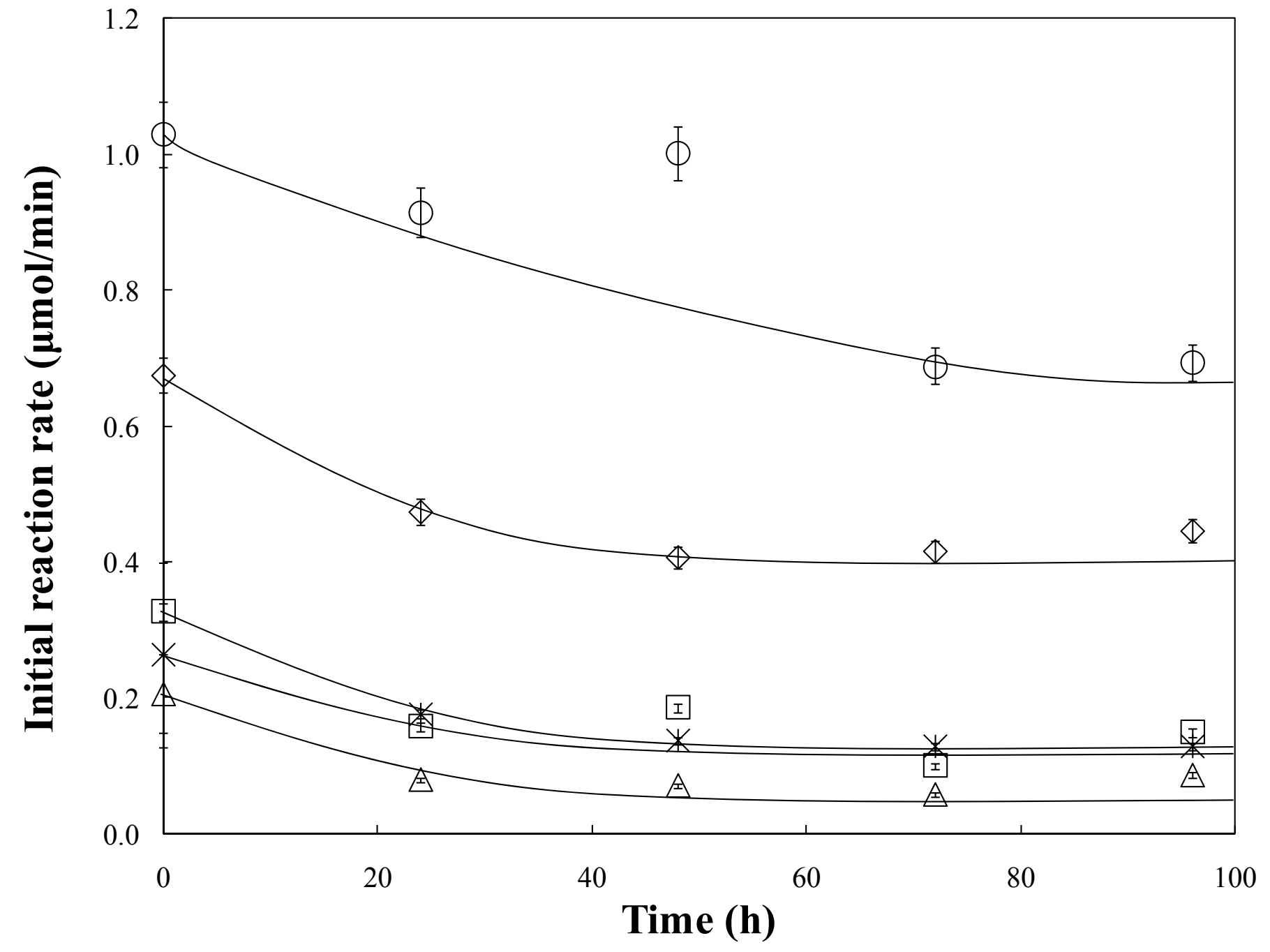

Fig. 9. Storage stability of CALB immobilized on fumed silica (FS) in n-hexane. ( $\diamond) 90$ wt.\% FS, ( $\square$ ) 95 wt.\% FS, (*) 98.5 wt.\% FS, $(\Delta) 99$ wt.\% FS. ( $($ ) Novozym 435 shown for comparison. Solid lines added to guide the eye; y-error bars represent the cumulative standard error from the calculation of conversion and the linear assumption of the initial reaction rate. 


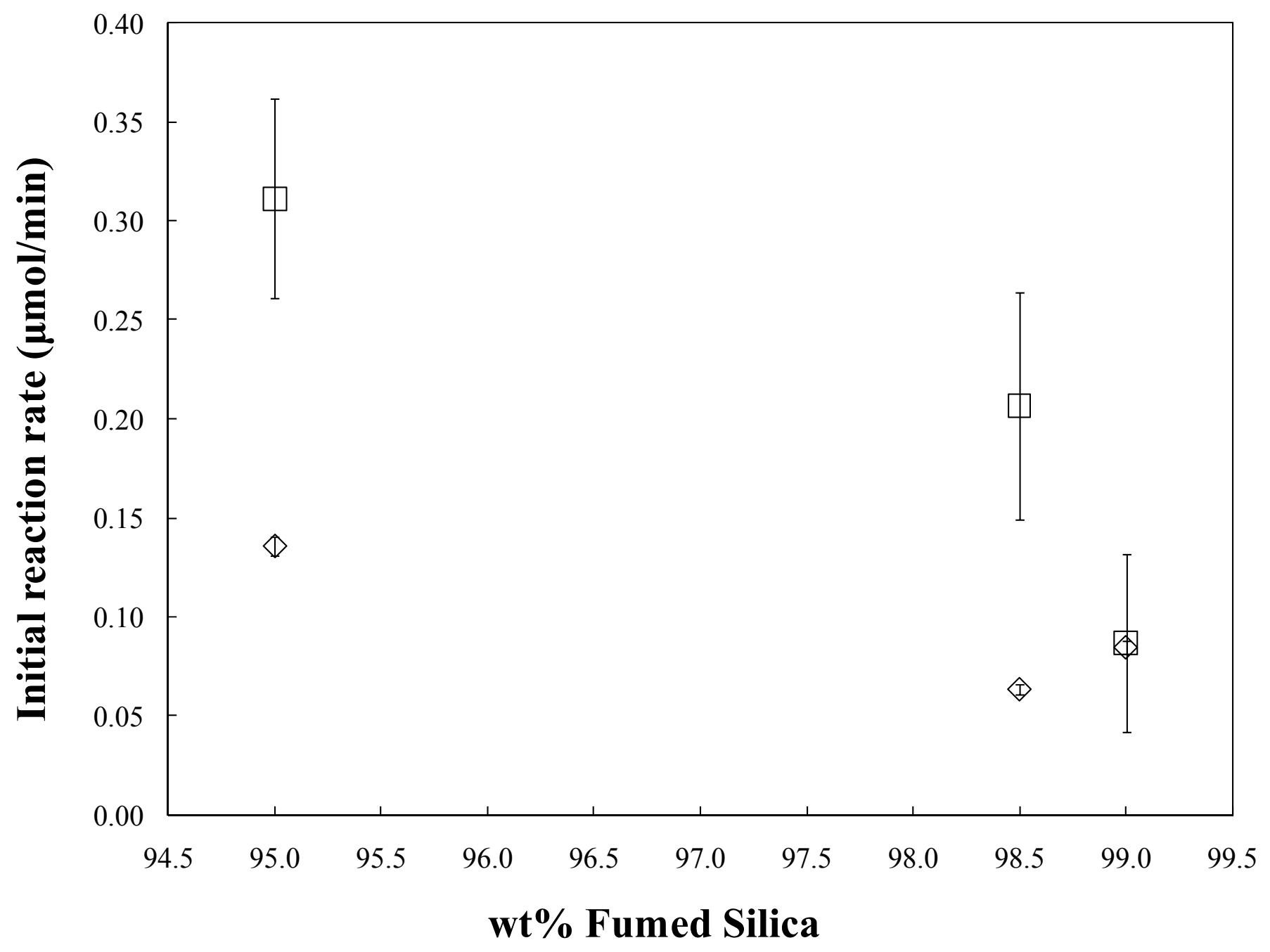

Fig. 10. Long-term stability of CALB immobilized on fumed silica as a function of the fumed silica content: $(\square)$ fresh preparation, $(\diamond)$ 6 months-aged preparation $\left(4^{\circ} \mathrm{C}\right.$, closed glass vials). y-error bars represent the cumulative standard error from the calculation of conversion and the linear assumption of the initial reaction rate. 